\title{
IMPROVEMENT OF REACTION TIME AFTER A WORKPLACE PHYSICAL ACTIVITY INTERVENTION
}

\author{
MELHORA DO TEMPO DE REAÇÃO APÓS INTERVENÇÃO COM EXERCÍCIOS FÍSICOS NO AMBIENTE \\ DETRABALHO
}

Original Article

ARtigo OrIGINAL

Artículo Original

\begin{abstract}
MEJORA DEL TIEMPO DE REACCIÓN DESPUES DE INTERVENCIÓN CONEJERCÍCIOS FISICOS EN EL AMBIENTEDETRABAJO
\end{abstract}

Rafael Cunha Laux ${ }^{1}$

(Physical Education Professional)

Sara Teresinha Corazza²

(Physical Education Professional)

1. Universidade do Oeste de Santa Catarina, Chapecó, SC, Brazil. 2. Universidade Federal de Santa Maria, Santa Maria, RS, Brazil.

\section{Correspondence:}

Rafael Cunha Laux. Avenida Nereu Ramos, 3777-D, Seminário, Chapecó, SC, Brazil. 89813-000. rafael.laux@unoesc.edu.br

\begin{abstract}
Introduction: Work activities have been occupying an increasing amount of time in the daily lives of the population, making individuals less physically active. A job market strategy is to invest in physical exercise programs in the actual workplace to improve the physical and cognitive aspects of these employees. Objective: To verify the effects of a workplace physical exercise program on the simple and choice reaction times of public university employees. Methods: Twenty-six physically inactive male and female subjects with a mean age of $29.62 \pm 6.47$ years underwent a program consisting of thirty-six sessions with physical exercises in the workplace, held three times a week over twelve weeks. Simple reaction time (SRT) and choice reaction time (CRT) were assessed before and after the intervention, using the Vienna Test System ${ }^{\circledR}$, and the results were presented in: I) reaction time, II) movement time; and (III) response time. Descriptive and inferential statistical analyses were conducted using the statistical program SPSS ${ }^{\circledR}$ (version 21.0 for Windows), with a significance level of 5\%. Results: When observing the SRT and CRT variables before and after the experiment, we noticed an improvement in reaction time, movement time and response time in the experimental group but not in the control group. Conclusion: The workplace physical exercise program was able to reduce the SRT and CRT of the experimental group. Level of evidence I; randomized clinical trial.
\end{abstract}

Keywords: Reaction time; Exercise; Public sector.

\section{RESUMO}

Introdução: As atividades laborais têm ocupado cada vez mais tempo no cotidiano da população, tornando os indivíduos menos ativos fisicamente. Uma estratégia do mercado de trabalho é investir em programas de exercícios físicos no próprio ambiente de trabalho visando melhorar os aspectos físicos e cognitivos desses colaboradores. Objetivos: Verificar os efeitos de um programa de exercícios físicos no ambiente de trabalho sobre o tempo de reação simples e de escolha em servidores públicos de uma universidade. Métodos: Vinte e seis sujeitos de ambos os sexos e fisicamente inativos, com idade média de 29,62 $\pm 6,47$ anos, foram submetidos a um programa de 36 sessões com exercícios físicos no ambiente de trabalho, distribuídas em três vezes por semana durante doze semanas. Foram avaliados, antes e após a intervenção, o tempo de reação simples (TRS) e o tempo de reação de escolha (TRE) através do Vienna Test System ${ }^{\circledR}$. Os resultados foram apresentados em:I) tempo de reação, II) tempo de movimento e III) tempo de resposta. As análises estatísticas descritivas e inferenciais foram realizadas utilizando-se o programa estatístico SPSS ${ }^{\circledR}$ (versão 21.0 para Windows), com grau de significância de 5\%. Resultados: Ao observar as variáveis do TRS e TRE antes e após o experimento, verificou-se no grupo experimental melhora no tempo de reação, tempo de movimento e tempo de resposta, o que não ocorreu no grupo controle. Conclusão: 0 programa de exercícios físicos no ambiente de trabalho foi capaz de reduzir o TRS e TRE do grupo experimental. Nível de evidência l; estudo clínico randomizado.

Descritores: Tempo de reação; Exercício; Setor público.

\section{RESUMEN}

Introducción: Las actividades laborales han ocupado cada vez más tiempo en el cotidiano de la población, haciendo con que los individuos sean menos activos físicamente. Una estrategia del mercado de trabajo es invertir en programas de ejercicios físicos en el propio ambiente de trabajo buscando mejorar los aspectos físicos y cognitivos de esos colaboradores. Objetivos: Verificar los efectos de un programa de ejercicios físicos en el ambiente de trabajo sobre el tiempo de reacción simple y de elección en servidores públicos de una universidad. Métodos: Veintiséis sujetos de ambos sexos y físicamente inactivos, con una edad promedio de 29,62 $\pm 6,47$ años, fueron sometidos a un programa de treinta y seis sesiones con ejercicios físicos en el ambiente de trabajo, distribuidas en tres veces por semana durante doce semanas. Fueron evaluados antes y después de la intervención, el tiempo de reacción simple (TRS) y el tiempo de reacción de elección (TRE) a través del Vienna Test System ${ }^{\circledR}$. Los resultados fueron presentados en: i) tiempo de reacción, ii) tempo de movimiento; yiii) el tiempo de respuesta. Los análisis estadísticos descriptivos e inferenciales se realizaron usándose el programa estadístico SPSS ${ }^{\circledR}$ (versión 21.0 para Windows) con un nivel de significancia del $5 \%$. 
Descriptores: Tiempo de reacción; Ejercicio; Sector público.

\section{INTRODUCTION}

Despite evidence that exercise can decrease morbidity and mortality ${ }^{1}$ and offer cognitive benefit, such as improved reaction time, ${ }^{2}$ about $31 \%$ of the world's population do not meet minimum exercise recommendations. This fact is even more worrying in the United States, where $43 \%$ of the population do not meet the minimum exercise recommendations. ${ }^{3}$

One effective method for increasing exercise is by offering exercise programs in the workplace because an adult subject spends more than half of his or her waking hours at these places. ${ }^{4}$

Workplace physical exercise interventions have proven beneficial for their participants. Among the main benefits are a reduction in muscle pain, improved seating posture, ${ }^{5}$ increased practice of physical exercise, ${ }^{6}$ fewer sick notes, ${ }^{7}$ and reduced symptoms of depression and anxiety. ${ }^{8}$ However, experimental research on physical exercise in the workplace and motor skills, especially reaction time, is scarce, or does not allow conclusive results regarding this variable., ${ }^{9,10}$

It is important to conduct research to improve reaction time, as this is an indication of cognitive capacity and psychomotor response, fundamental aspects of human behavior in the productive work environment. ${ }^{2}$ Studies on physical exercise already indicate superior results for active subjects or those with better athletic performance in reaction time. ${ }^{2,11}$ However, there is no consensus on reaction time results when subjects undergo different types of physical exercise and varied intervention, duration, and intensity protocols. In order to contribute to this issue, the aim of this study was to verify the effects of a structured program of short physical exercise on simple and choice reaction time among civil servants in the workplace, at a university.

\section{METHODS}

A randomized controlled trial study ${ }^{12}$ was conducted at a public university in western Santa Catarina state. The chronic effect of the PEFAT program was tested, after 36 sessions that were conducted 3 times a week for 12 weeks.

Twenty-six physically inactive subjects of both sexes, aged 18 to 50, classified as Sedentary or Insufficiently Active A and B, according to the short International Physical Activity Questionnaire (IPAQ, 7-items version), during the intervention period, who did not use medication that had an effect on the central nervous system, and who had a minimum of 75\% attendance in the exercise program, were recruited for the study (Figure 1).

Half of the subjects, randomly selected by lot, participated in the intervention (experimental group), and the other half did not engage in any type of exercise (control group).

The study was approved by the Research Ethics Committee of the Federal University of Santa Maria, through CAAE no. 53085216.5.0000.5346. It observed all ethical standards required by Resolution 466/12 of the National Health Council. All study subjects signed the Informed Consent Form.

The characterization of the group was performed using anamnesis, anthropometric assessment, and assessment of the level of participation in physical activity. In the selection of the subjects, anamnesis was used to collect data on age, gender, medication use, and physical and psychological trauma.

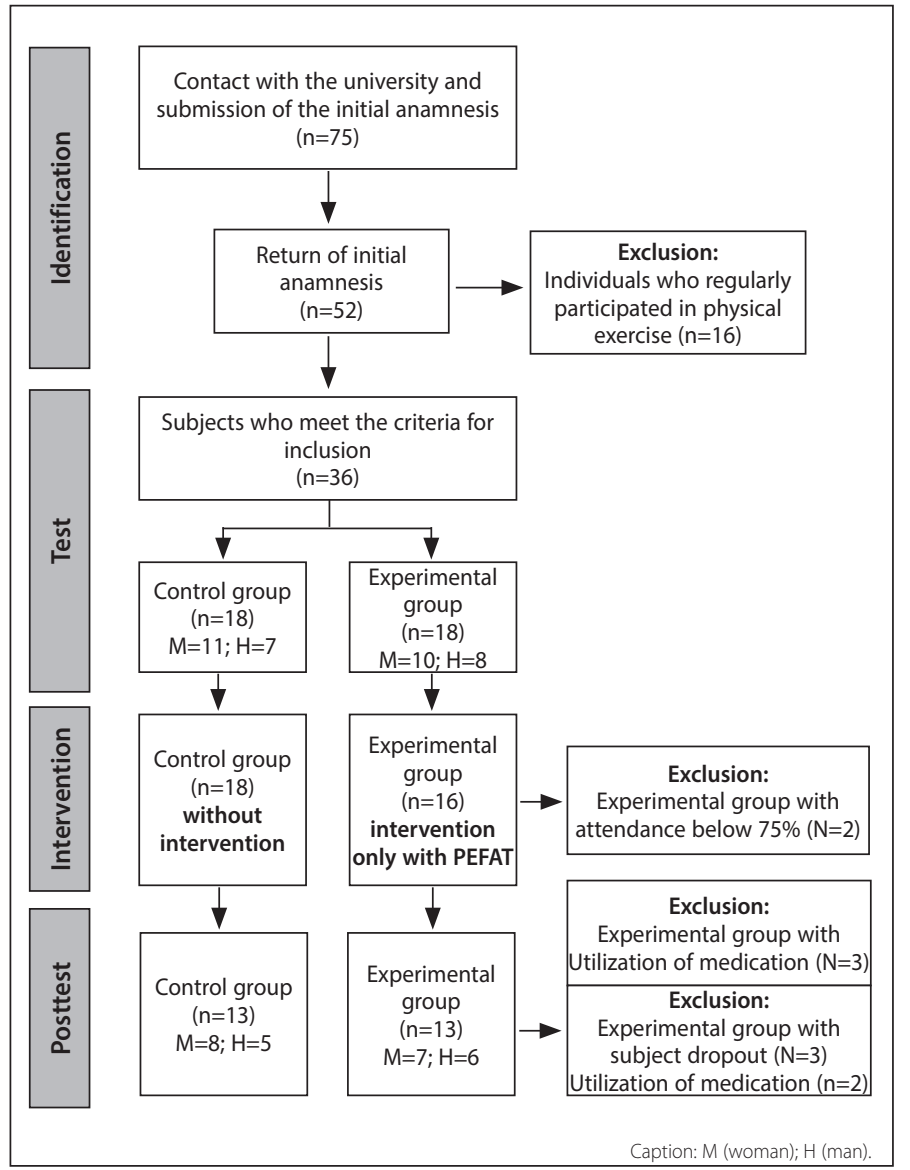

Figure 1. Selection of subjects and design of the study.

The anthropometric evaluation consisted of the measurement of body mass and height, using a Filizola digital resolution scale (São Paulo, Brazil) and a Cescorf stadiometer (Porto Alegre, Brazil) with $0.1 \mathrm{~cm}$ resolution, according to the protocol of the International Society for the Advancement of Kinanthropometry. ${ }^{13}$ The evaluations were performed by a trained evaluator. Body mass index calculation followed the World Health Organization protocol. ${ }^{14}$

The level of daily physical exercise was measured using the short $I P A Q$, validated by Matsudo et al. ${ }^{15}$ According to the classification criteria of the IPAQ, the subject is considered a) Sedentary when not performing any physical exercise for at least 10 continuous minutes during the week; b) Insufficiently Active A when performing 10 continuous minutes of physical activity (walking + moderate + vigorous), with a frequency of 5 days a week or weekly duration of 150 minutes; and c) Insufficiently Active $B$ when he or she does not meet any of the recommended criteria mentioned for individuals who are Insufficiently Active $A .{ }^{16}$

The simple reaction time (SRT) and the choice reaction time (CRT) were evaluated with the Vienna Test System, Version 6.81.013 (SCHUHFRIED, Moedling, Austria). Serial Number 023714/01, installed on a CCE WIN model laptop with Intel Celeron CPU 1037 U @ 1.80Ghz, 2GB RAM processor, Windows 8.1 operating system with Bing 64-bit, x64-based processor, 00266-70119-01541-AAOEM product key, with network card 
disabled. The evaluation system consists of a universal response panel, a motor performance panel coupled to a laptop, and a headset. The SRT was evaluated using the $\mathrm{S} 1$ version of the simple reaction test, which consists of presenting a visual stimulus (yellow light), which should be answered as soon as possible. The evaluation protocol consists of training attempts and the test with 28 stimuli; all require a reaction. To evaluate the CRT, we used the $\mathrm{S} 3$ version of the choice reaction test, which consists of alternating red, yellow, and sound-light stimuli, and combinations of these stimuli. In this test, the subject should react only when an acoustic stimulus with the yellow visual stimulus is present, and the response to other commands will be counted as an error. The evaluation protocol consists of training attempts and the test with 48 stimuli, 16 of which require a reaction. ${ }^{17}$

Results are presented in milliseconds and divided as follows: I) reaction time (from stimulus presentation to response onset), II) movement time (from beginning to end of response), and III) response time (the sum of reaction and movement time)..$^{18}$

The PEFAT was performed 3 times a week for 12 weeks, for a total of 36 classes ( 6 hours of activities). Each session lasted 10 minutes, consisting of the initial, main, and final part (Figure 2), with emphasis on playful activities in the initial part, based on the protocol proposed by Laux, Corazza and Andrade. ${ }^{19}$ In the main part, exercises were performed, along with muscle strengthening and flexing in proportional quantities.

The initial part lasted 4 minutes, and the main activities were dribbling between cones, warming up in place, and exercising to music. For dribbling between cones, subjects were arranged in a column. One person took a rubber ball and zigzagged between the cones as he or she dribbled the ball and returned and handed the ball to the next person to perform the task. For warming up in place, the subjects were arranged in a circle. They performed movements, interspersing several repetitions of knee elevation and knee flexion. For exercising to music, the subjects were freely arranged around the room and performed leg abduction and adduction movements to music, step open and close, adding elements such as arm raising and clapping as coordination improved. ${ }^{19}$

The main part, consisted of 5 minutes of flexion exercises and 4 minutes of muscle strengthening exercises (Figure 2). In flexion sessions, the intensity was maximal, with exercises for all body parts, especially the cervical region, shoulder region, spinal region, and lower limbs. For the cervical region, subjects performed flexion, head, and cervical extension movements while standing. For the shoulder region, in the same position as the previous exercise, the subjects performed an arm adduction horizontally. For the spinal region, with the trunk flexed in front, the subject performed a lateral rotation movement. For the lower limbs, standing, the subject extended the thigh with flexed legs. ${ }^{19}$

In the muscular reinforcement session, isometric and dynamic exercises were performed, primarily curved rowing, the inverse crucifix, and squats. For the curved rowing exercises, the subject keeps the feet laterally separated, with the knees semi-flexed and the trunk inclined forward; in this position, he or she bends the stick in the direction of the navel, and returns to the original position. For the inverse crucifix, in the same position as the preceding exercise, the subject makes a movement of horizontal

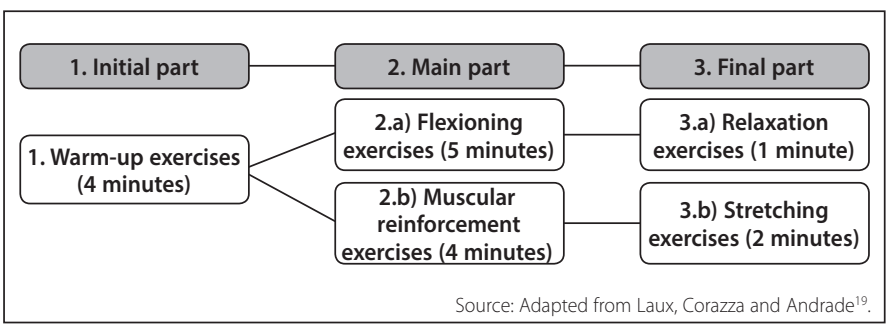

Figure 2. Structure of the sessions of the PEFAT. extension of the shoulder. To perform squats, in the standing position, the subject maintains separation of the lower members at a slightly wider width than that of the shoulders, to begin descent projecting the gluteus backward until reaching a $90^{\circ}$ angle, returning to the original position. ${ }^{19}$

As shown in Figure 2, in the sessions with flexion exercises, relaxation activities were performed at the end. These activities included the sitting massage, meditation, balloon play, and stretching. To perform the sitting massage, in pairs, one of the subjects sat while the other performed shoulder and back massage movements. To meditate, subjects sat with their eyes closed and were given commands to aid them in transitioning to a relaxed state. Balloon play was also performed. In balloon play, subjects were freely arranged in the room and were to prevent their balloon and those of their colleagues from falling to the floor, using only their heads as "rackets," for 1 minute. In the sessions with muscle strengthening exercises, in the final part, stretches were performed, which basically involved the same flexion exercises with a submaximal work intensity. ${ }^{19}$

The intensity of the exercises was controlled using the Subjective Effort Perception Scale, ${ }^{20}$ in order to remain between slightly intense and intense levels (13-15 points on the scale) during the session.

Data normality was verified using the Shapiro-Wilk test, which identified a parametric distribution. The t test was used for comparison between groups, and the paired t test to compare pretest and posttest results. For the analysis between the preintervention and postintervention IPAQ classifications, Fisher's exact test was used. Descriptive and inferential statistical analyses were performed using the statistical program SPSS (version 21.0 for Windows) (IBM Corp, Armonk, NY, USA), with a significance level of $5 \%$.

\section{RESULTS}

Twenty-six physically inactive subjects (Table 1) participated in the study. Their mean age was $29.62 \pm 6.47$ years. They were subdivided into 2 groups of 13 subjects each: the control group (8 women and 5 men) and the experimental group (7 women and 6 men).

In observing the SRT variables (Table 2), one perceives a diminution in the comparison between pretest and posttest results in the experimental group ( $p<0.01$ ), which did not occur in the control group $(p=0.25, p=0.82$ and $p=0.52$ ). In the comparison between the groups, it was verified that only in movement time there was a difference between the control group and the experimental group after intervention $(p<0.01)$.

Similar results were found for CRT (Table 3 ) as had been found for SRT. A decrease was observed in the comparison of pretest and posttest results in the experimental group $(p=0.01 ; p<0.01$ and $p<0.01)$, and without significant changes in the control group $(p=0.08 ; p=0.91$ and $p=0.17$ ). In the comparisons between groups, no differences were observed between the control group and the experimental group in the preintervention and postintervention periods.

Table 1. Characteristics of the Study Group.

\begin{tabular}{|c|c|c|c|c|c|c|}
\hline & \multicolumn{2}{|c|}{$\begin{array}{c}\text { Control group } \\
(n=13)\end{array}$} & & \multicolumn{2}{|c|}{$\begin{array}{l}\text { Experimental } \\
\text { group }(n=13)\end{array}$} & \multirow[b]{2}{*}{$\mathbf{P}$} \\
\hline & Mean & SD & & Mean & SD & \\
\hline Age (years) & 29.77 & 5.61 & & 29.46 & 7.46 & $0.91^{\mathrm{a}}$ \\
\hline Body mass $(\mathrm{kg})$ & 73.68 & 16.10 & & 73.96 & 18.31 & $0.97^{a}$ \\
\hline Height (m) & 1.67 & 0.08 & & 1.68 & 0.09 & $0.71^{a}$ \\
\hline BMI $\left(\mathrm{kg} / \mathrm{m}^{2}\right)$ & 26.52 & 6.33 & & 25.83 & 4.96 & $0.76^{a}$ \\
\hline \multirow[t]{2}{*}{$\mathrm{IPAQ}$} & Pre & Post & & Pre & Post & \\
\hline & $\mathrm{n}(\%)$ & $\mathrm{n}(\%)$ & $\mathrm{p}$ & $\mathrm{n}(\%)$ & $\mathrm{n}(\%)$ & $\mathrm{p}$ \\
\hline Insufficiently Active & $6(46 \%)$ & $8(62 \%)$ & \multirow{2}{*}{$0.69^{b}$} & $3(23 \%)$ & $6(46 \%)$ & \multirow{2}{*}{$0.41^{b}$} \\
\hline Insufficiently Active B & $7(54 \%)$ & $5(38 \%)$ & & $10(77 \%)$ & $7(54 \%)$ & \\
\hline
\end{tabular}

BMI, body mass index; IPAQ, International Physical Activity Questionnaire; M, mean; SD, standard deviation. test. ${ }^{b}$ Fisher's exact test. * $p<0,05$. Captions: SD (standard deviation); P (statistical value of the tests performed). 
Table 2. Simple Reaction Time.

\begin{tabular}{|c|c|c|c|c|c|c|}
\hline & & $\begin{array}{l}\text { Control } \\
\text { group }\end{array}$ & & $\begin{array}{c}\text { Experimental } \\
\text { group }\end{array}$ & & \multirow{2}{*}{$\begin{array}{c}\text { Between-group } \\
p\end{array}$} \\
\hline & & $\mathrm{M} \pm \mathrm{SD}$ & $P$ & $\mathrm{M} \pm \mathrm{SD}$ & $p$ & \\
\hline \multirow{2}{*}{$\begin{array}{l}\text { Reaction } \\
\text { time (ms) }\end{array}$} & Pre & $314.23 \pm 58.57$ & \multirow{2}{*}{$0.25^{a}$} & $352.38 \pm 52.46$ & \multirow{2}{*}{$<0.01^{a *}$} & $0.09^{b}$ \\
\hline & Post & $320.54 \pm 51.52$ & & $319.69 \pm 49.60$ & & $0.97^{b}$ \\
\hline \multirow{2}{*}{$\begin{array}{c}\text { Movement } \\
\text { time (ms) }\end{array}$} & Pre & $206.00 \pm 59.03$ & \multirow{2}{*}{$0.82^{\mathrm{a}}$} & $211.00 \pm 48.76$ & \multirow{2}{*}{$<0.01^{\mathrm{a} *}$} & $0.82^{b}$ \\
\hline & Post & $208.62 \pm 49.45$ & & $155.31 \pm 40.46$ & & $<0.01^{\mathrm{b \#}}$ \\
\hline \multirow{2}{*}{$\begin{array}{l}\text { Response } \\
\text { Time (ms) }\end{array}$} & Pre & $520.20 \pm 104.40$ & \multirow{2}{*}{$0.52^{\mathrm{a}}$} & $563.40 \pm 77.30$ & \multirow{2}{*}{$<0.01^{a *}$} & $0.24^{b}$ \\
\hline & Post & $529.20 \pm 90.10$ & & $475.00 \pm 79.00$ & & $0.12^{b}$ \\
\hline
\end{tabular}

M, mean; Post, postintervention; Pre, preintervention; MLS, milliseconds; $S D$, standard deviation. ${ }^{a}$ paired t test. ${ }^{b}$ test. " $p<0.05$. Captions: M (mean); SD (standard deviation); P (statistical value of the tests performed); MLS (milliseconds).

Table 3. Choice Reaction Time

\begin{tabular}{|c|c|c|c|c|c|c|}
\hline & & $\begin{array}{l}\text { Control } \\
\text { group }\end{array}$ & & $\begin{array}{c}\text { Experimental } \\
\text { group }\end{array}$ & & \multirow{2}{*}{$\begin{array}{c}\text { Between-group } \\
\text { P }\end{array}$} \\
\hline & & $\mathrm{M} \pm \mathrm{SD}$ & $\mathrm{P}$ & $\mathrm{M} \pm \mathrm{SD}$ & $\mathbf{P}$ & \\
\hline \multirow{2}{*}{$\begin{array}{l}\text { Reaction } \\
\text { time (ms) }\end{array}$} & Pre & $451.54 \pm 71.27$ & \multirow{2}{*}{$0.08^{a}$} & $473.62 \pm 67.82$ & \multirow{2}{*}{$0.01^{a *}$} & $0.43^{b}$ \\
\hline & Post & $421.46 \pm 84.83$ & & $437.46 \pm 75.95$ & & $0.62^{b}$ \\
\hline \multirow{2}{*}{$\begin{array}{c}\text { Movement } \\
\text { time (ms) }\end{array}$} & Pre & $220.69 \pm 61.18$ & \multirow{2}{*}{$0.91^{a}$} & $229.15 \pm 48,59$ & \multirow{2}{*}{$<0.01^{\mathrm{a} *}$} & $0.70^{b}$ \\
\hline & Post & $222.15 \pm 62.71$ & & $179.38 \pm 45.67$ & & $0.06^{b}$ \\
\hline \multirow{2}{*}{$\begin{array}{l}\text { Response } \\
\text { time (ms) }\end{array}$} & Pre & $672.23 \pm 119.40$ & \multirow{2}{*}{$0.17^{a}$} & $702.77 \pm 90.50$ & \multirow{2}{*}{$<0.01^{a *}$} & $0.47^{b}$ \\
\hline & Post & $643.62 \pm 131.85$ & & $616.85 \pm 103.80$ & & $0.57^{b}$ \\
\hline
\end{tabular}

M, mean; Post, postintervention; Pre, preintervention; MLS, milliseconds, SD, standard deviation. ${ }^{a}$ paired t test ${ }^{b}$ t tes " $p<0.05$. Captions: M (mean); SD (standard deviation); P (statistical value of the tests performed); MLS (milliseconds).

\section{DISCUSSION}

When verifying the effects of a structured program of short physical exercise on simple and choice reaction time among civil servants at a university, in the work environment, it was observed that there was improvement of all the studied variables in the comparison between the pretest and posttest in the experimental group, which did not occur in the control group.

The findings of this study contrast with those of Mezzomo, Contreira, and Corazza ${ }^{9}$ and Mezzomo et al., ${ }^{10}$ in their research on physical exercise programs in the workplace. In the study conducted with employees in the administrative sectors, they found no pre-post differences in the assessment of reaction time, ${ }^{9}$ nor between experimental and control groups in the study with bus drivers. ${ }^{10}$ However, it is noteworthy that in both studies medication intake was not controlled during the period or on the evaluation day, and most drugs directly influence the central nervous system and may affect the subjects' reaction times..$^{21,22}$

Other methodological differences among these investigations, such as the absence of a control group ${ }^{9}$ or pretesting of the subjects to be submitted to the exercise program, ${ }^{10}$ which made impossible more conclusive results, ${ }^{12}$ may have been responsible for these differences. Furthermore, in those studies, a teaching methodology based on traditional gym classrooms was employed. The findings in the present study may have differed for this reason. This reinforces the importance of the classroom structure and organization proposed by Laux et al. ${ }^{7}$ and Laux, Corazza and Andrade. ${ }^{19}$
The efficacy of the PEFAT acquires importance due to the correlation between reaction time and cognitive functioning found in the study by Collins and Longo. ${ }^{23}$ Authors Stuss et al. ${ }^{24}$ and Stubbs et al..$^{25}$ mention the need to develop interventions that reduce sedentary behavior, promote the practice of physical activity, and improve reaction times, considering that the natural ageing process is responsible for performance reduction on that variable, and consequently of cognitive functioning. ${ }^{26}$ Fozard et al. ${ }^{27}$ emphasize in their longitudinal study that this increase in reaction time is continuous throughout adulthood, and that this also occurs with the number of incorrect responses to environmental stimuli.

Maintaining or improving reaction time is necessary, in order to avoid vulnerable or dangerous situations, such as collisions with objects, through faster neuromuscular responses. ${ }^{27}$ In the workplace, dangerous situations that provoke accidents are common. In 2017, in Brazil, the incidence was 13.74 accidents per thousand employment contracts. ${ }^{28}$

Despite the small number of experimental studies on PEFAT and reaction time, there are numerous studies on the benefits of physical exercise that investigate reaction time, such as Gierczuk, Lyakh and Sadowski, ${ }^{11}$ who evaluated elite Greco-Roman fighters and observed a shorter visual simple reaction time for the group of finalists, compared with the group that did not reach the final. It has been noted that the positive influence of physical exercise on reaction time is observed for both acute effect ${ }^{2}$ and chronic effect. ${ }^{29}$ However, it is noteworthy that the amount of physical exercise, intensity, and duration to improve cognitive function, such as reaction time, are not clear in literature. ${ }^{30}$

This study had some limitations. There was a small number of subjects and limited time for application of the program. However, the rigorous selection of subjects and the application of the intervention in their own work environment strengthen the findings of this study and its application in the daily life of institutions. The findings of this study can improve employees' simple and choice reaction times and, consequently, improve productivity and assist in reducing sick notes.

\section{CONCLUSION}

In conclusion, the present study shows an improvement in simple reaction time, choice reaction time, movement time, and response time in subjects undergoing a structured program of short physical exercise in the workplace, showing the effectiveness of this type of intervention in improving cognitive functioning.

\section{ACKNOWLEDGMENTS}

Special thanks to CAPES, which enabled the research through the master's fellowship for the first author.

All authors declare no potential conflict of interest related to this article

AUTHORS' CONTRIBUTIONS: Each author made significant individual contributions to this manuscript. RCL (0000-0003-2723-3130)*: conception and preparation of the intervention protocol, research and structuring of the article, final approval of the manuscript version to be published; STC (0000-0002-2684-2412)*: critical review of the article, collaboration in the preparation of the program. ${ }^{*} \mathrm{ORCID}$ (Open Researcher and Contributor ID).

\section{REFERENCES}

1. Hamilton MT, Hamilton DG, Zderic TW. Role of low energy expenditure and sitting on obesity, metabolic syndrome, type 2 diabetes, and cardiovascular disease. Diabetes. 2007;56(11):2655-67.

2. Ozyemisci-Taskiran O, Gunendi Z, Bolukbasi N, Beyazova M. The effect of a single session submaxima aerobic exercise on premotor fraction of reaction time: An electromyographic study. Clin Biomech (Bristol, Avon). 2008;23(2):231-5.

3. Hallal PC, Andersen LB, Bull FC, Guthold R, Haskell W, Ekelund U. Global physical activitylevels: Surveillance progress, pitfalls, andprospects. Lancet. 2012;380(9838):247-57.
4. Conn VS, Hafdahl AR, Cooper PS, Brown LM, Lusk SL. Meta-Analysis of Workplace Physical Activity Interventions. Am J Prev Med. 2009:37(4):330-9.

5. Candotti CT, Stroschein R, Noll M. Efeitos da ginástica laboral na dor nas costas e nos hábitos posturais adotados no ambiente de trabalho. Rev Bras Ciênc Esporte. 2011;33(3):699-714.

6. Grande AJ, Loch MR, Guarido EA, Costa JBY, Grande GC, Reichert FF. Comportamentos relacionados à saúde entre participantes e não participantes da ginástica laboral. Rev Bras Cineantropom Desempenho Hum. 2011;13(2):131-7. 
7. Laux RC, Pagliari P, Effting Junior JV, Corazza ST. Ginástica Laboral e a redução de atestados médicos. Cienc Trab. 2016;18(56):130-3.

8. Chu AHY, Koh D, Moy FM, Müller-Riemenschneider F. Do workplace physical activity interventions improve mental health outcomes? Occup Med (Lond). 2014;64(4):235-45.

9. Mezzomo SP, Contreira AR, Corazza ST. Os efeitos da ginástica laboral sobre as habilidades básicas de funcionários de setores administrativos. Rev Bras Ciênc Saúde. 2010;8(25):6-13.

10. Mezzomo S, Cardozo PL, Katzer Jl, Dos Santos DL, Corazza ST. A influência da ginástica laboral na coordenação motora global e no tempo de reação de condutores de autocarro. Motricidade. 2014;10(4):24-37.

11. Gierczuk D, Lyakh V, Sadowski J. Speed of Reaction and Fighting Effectiveness in Elite Greco-Roman Wrestlers. Percept Mot Skills. 2017;124(1):200-13.

12. Thomas JR, Nelson JK, Silverman S. Métodos de pesquisa em atividade física. $6^{\text {a }}$ ed. Porto Alegre: Artmed; 2012.

13. Marfell-jones M, Olds T, Stewart A, Carter L. International standards for anthropometric assessment. Potchefstroom. South Africa: ISAK; 2006

14. World Health Organization. Obesity and overweight. Factsheet $n^{\circ} 311.2015$. [Acesso em 03 jun. 2018] Disponível em: https://www.who.int/news-room/fact-sheets/detail/ obesity-and-overweight

15. Matsudo S, Araújo A, Matsudo V, Andrade D, Andrade E, Oliveira LC, et al. Questionário internacional de atividade física (IPAQ): estudo de validade e reprodutibilidade no brasil. Rev Bras Ativ Fís Saúde. 2001:6(2):5-18

16. Silva GSF, Bergamaschine R, Rosa M, Melo C, Miranda R, Bara FM. Evaluation of the physical activity level of undergraduation students of health / biology fields. Rev Bras Med Esporte. 2007;13(1):39-42.

17. Prieler J. Reaction test. Version 31. Lisboa: Mödling; 2008.

18. Hainaut JP, Bolmont B. Effects of Mood States and Anxiety as Induced by the Video-Recorded Stroop Color-Word Interference Test in Simple Response Time Tasks on Reaction Time and Movement Time. Percept Mot Skills. 2005;101(3):721-9.
19. Laux RC, Corazza ST, Andrade A. Workplace physical activity program: an intervention proposal. Rev Bras Med Esporte. 2018;24(3):238-42.

20. Borg G. Escalas de Borg para a dor e o esforço percebido. São Paulo: Manole; 2000.

21. Littleton AC, Schmidt JD, Register-Mihalik JK, Gioia GA, Waicus KM, Mihalik JP, et al. Effects of Attention Deficit Hyperactivity Disorder and Stimulant Medication on Concussion Symptom Reporting and Computerized Neurocognitive Test Performance. Arch Clin Neuropsychol. 2015;30(7):683-93.

22. Naickera P, Anoopkumar-Dukiea S, Granta GD, Neumanna DL, Kavanagha JJ. Central cholinergic pathway involvement in the regulation of pupil diameter, blink rate and cognitive function. Neuroscience. 2016;334:180-90.

23. Collins LF, Long CJ. Visual reaction time and its relationship to neuropsychological test performance. Arch Clin Neuropsychol. 1996;11(7):613-23.

24. Stuss DT, Murphy HKJ, Binns MA, Alexander MP. Staying on the job: the frontal lobes control individual performance variability. Brain. 2003;126(Pt 11):2363-80.

25. Stubbs B, Ku PW, Chung MS, Chen LJ. Relationship Between Objectively Measured Sedentary Behavior and Cognitive Performance in Patients With Schizophrenia Vs Controls. Schizophr Bull. 2016;43(3):566-74.

26. Anstey KJ. Sensorimotor variables and forced expiratory volume as correlates of speed, accuracy, and variability in reaction time performance in late adulthood. Aging Neuropsychol C. 1999;6(25):84-95,

27. Fozard JL, Vercruyssen M, Reynolds SL, Hancock PA, Quilter RE. Age differences and changes in reaction time: The Baltimore Longitudinal Study of Aging. J Gerontol Psychol Sci. 1994;49(4):179-89.

28. Wilkerson GB, Simpson KA, Clark RA. Assessment and Training of Visuomotor Reaction Time for Football Injury Prevention. J Sport Rehabil. 2017;26(1):26-34.

29. Ministério da Fazenda. Anuário Estatístico de Acidentes do Trabalho: AEAT 2017. Brasília: Ministério da Fazenda; 2017

30. Antunes HKM, Santos RF, Cassilhas R, Santos RVT, Bueno OFA, Mello MT. Reviewing on physical exercise and the cognitive function. Rev Bras Med Esporte. 2006;12(2):97-103. 